\title{
Error Analysis in Optical Heterodyne Ellipsonetry
}

\author{
光ヘテロタイン偏光解析法における誤差要因の槚討
}

Toshihisa SATO and Hideshi YOKOTA

DEPARTMENT OF ELECTRO-PHOTO-OPTICS, FACULTY OF ENGINEERING TOKAI UNIVERSITY

1117 KITAKANAME, HIRATSUKA, KANAGATI, 259-12 JAPAN

( Accepted for publication 18 November 1993)

\section{1.はじめに}

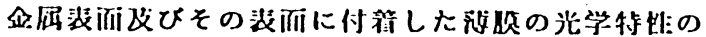

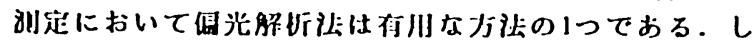

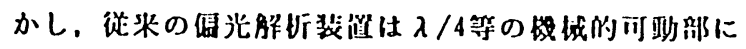

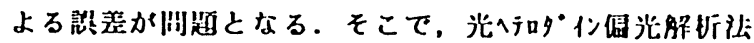

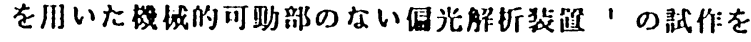
行った。

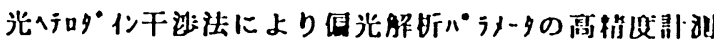

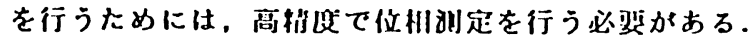

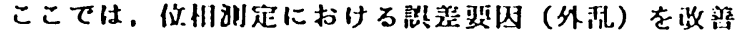

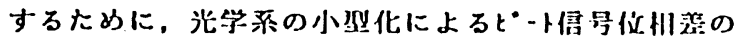

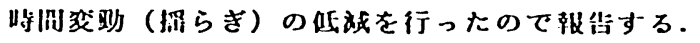

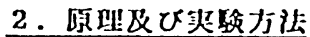

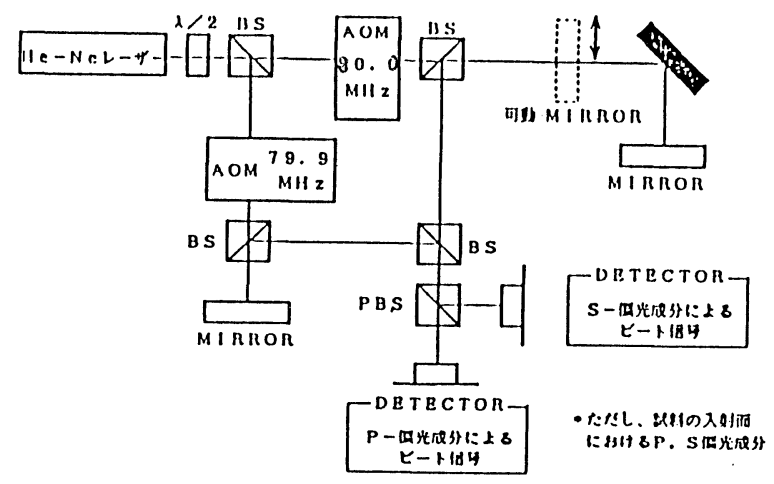

F i g. 1 光へ吅タ・イン・エリフ・ッルータ

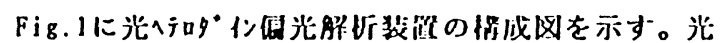

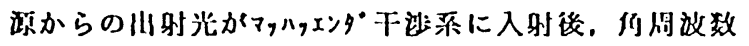

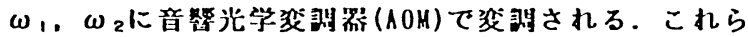

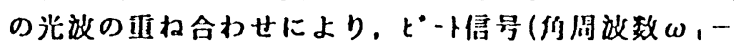
$\left.\omega_{2}\right)$ が众川される。このとき，試料により一力の光路

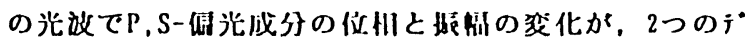

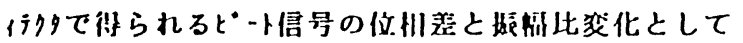

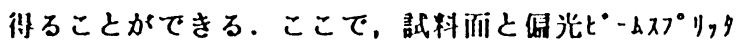
-(PBS)の入射而市は一政しているとする。このように。

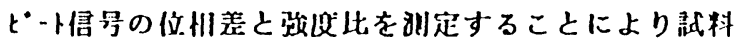

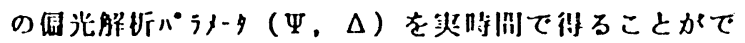

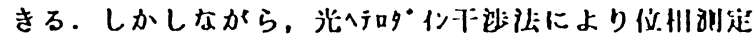

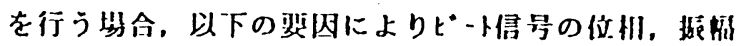

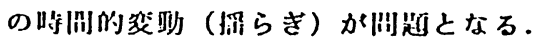

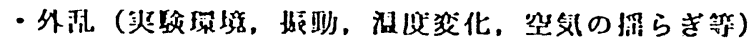

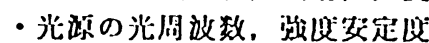

・ヒ・正周放数安还证

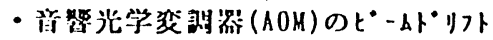

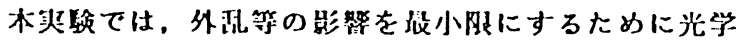

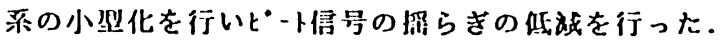

\section{3. 头馀棺果区ひ污祭}

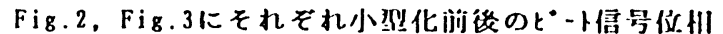
却の渭らきを示す。

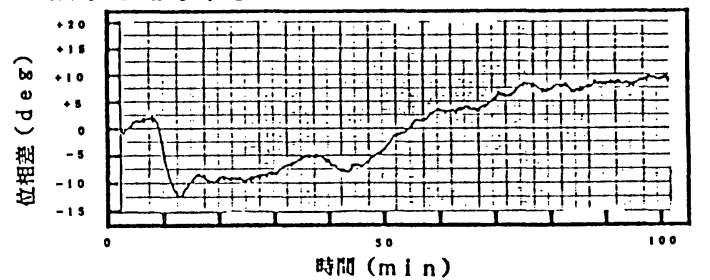

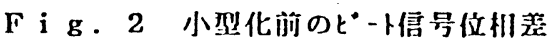
の罚らき(150×150)

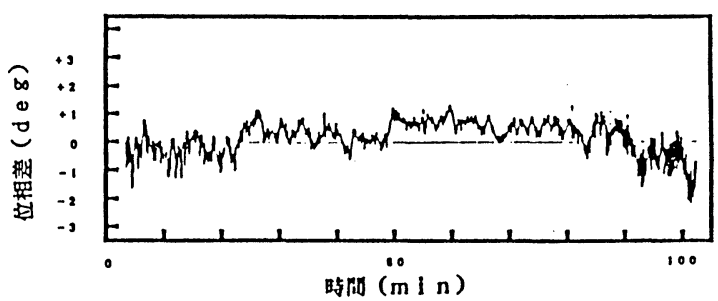

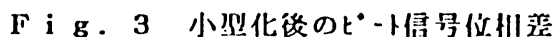
の罚らき $(30 \times 15)$

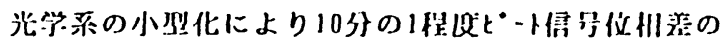

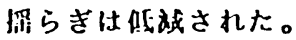

\section{3.まとめ及び今後の訓呴}

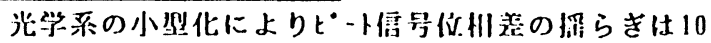

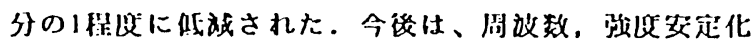

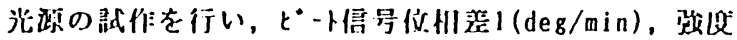
(0.1\%)の突起化を行う予起である.

\section{㗬考文献}

1 Chin-hwa Lin, Chien Chou and Ken-su Chang,

App1.0pt.29,5159-5162(1990)

'93 SAS Intelligent Symposium

(C) 1994 Society of Advanced Science 